\title{
Oprimido(s), da Pedagogia ao Teatro- Paulo Freire e Augusto Boal
}

\section{Bruna Carolini Biasi e Nima I. Spigolon( Faculdade de Educação, UNICAMP)}

\begin{abstract}
Resumo
A Pesquisa de IC tem como objeto de estudo a categoria Oprimido, dentro da obra Pedagogia do Oprimido, do Paulo Freire e Teatro do Oprimido, do Augusto Boal. A investigação vai no sentido da caracterização em que cada autor, em seu momento histórico, discute em relação do Oprimido e também seus apontamentos para a libertação do povo. A dominação massiva em que a classe capitalista emprega à classe explorada, nos controla e nos introjeta um sistema que nos impregna socialmente e culturalmente. Esses dois autores trazem discussões e propostas como ferramentas para a conscientização para pensar a realidade e poder transformá-la. Ou seja, nem a Educação e nem o Teatro sejam um fim em si mesmos, mas sim para busca de um novo mundo.
\end{abstract}

\section{Palavras-chave:}

Opressão, Oprimido(s), Libertação.

\section{Introdução}

O Teatro no Brasil, vinha de uma corrente na década de 50 de refletir uma linguagem de modo tipicamente brasileiro, que discuta questões políticas, estéticas e artísticas.

Paulo Freire através da sua proposta políticopedagógica, entende que os círculos de cultura inicialmente no Nordeste, e depois no Plano nacional de alfabetização. Expressam a capacidade humana de refletir sobre o mundo, sobre a posição humana no mundo e o poder de transformar o mundo por meio do trabalho, do diálogo, da educação e das práticas culturais.

Com o Golpe de 64, as Forças Armadas controlando o Estado. Na qual, evidenciou o verdadeiro papel do Estado Capitalista, a dominação. Com tudo isso é parte da IC o mapeamento das categorias Opressão, Oprimidos e Libertação, a partir destes autores, Paulo Freire e Augusto Boal, que escreveram esses textos em exílio político, e que influenciaram muito no debate da esquerda ao combate das opressões.

\section{Resultados e Discussão}

Paulo Freire denuncia no livro que a classe opressora e dominante por meio da Ideologia aparelham um sistema para a própria manutenção, que na educação é por meio da educação, chamada por ele, Bancária. E criou de proposta a educação Libertadora. Umas das passagens mais ricas, é quando Freire diz, que não dá para comparar a violência dos oprimidos com a dos opressores, a rebelião para o ato de libertação, é um ato de amor.

Augusto Boal, como Paulo Freire, falam que a classe dominante capitalista, usa de várias ferramentas para manutenção das opressões, e uma delas é o Teatro. E como proposta ele aponta para o Teatro do Oprimido.

\section{Conclusão}

A IC dá o devido destaque a Paulo Freire e Augusto Boal, a partir, respectivamente, da obra Pedagogia do Oprimido e do Teatro do Oprimido, documentos que foram tomados como referências básicas dos diálogos, das análises e das reflexões, ocorridas durante essa IC e nos processos de minha formação inicial de professora. Uma pedagogia e um teatro, ambos do Oprimido, se fazem necessários para que o ser humano possa libertar-se pela mediação dialógica e emancipadora da educação e da arte, que pode acontecer nas escolas, nos palcos e em todos os demais espaços culturais e com os sujeitos compromissados com a denúncia e a transformação das condições sociais e políticas opressoras, transformando-se e transformando suas realidades.

Ambos não tem a ilusão que a Educação e o Teatro irão acabar com o Estado Capitalista, São ferramentas que podem ser resistência contra as opressões.

\section{Agradecimentos}

À Nima pela oportunidade de realizar este trabalho. Ao Vitor, Lene, Giseli e Hosana que me fortalecem sempre. E a classe trabalhadora que nos dão a experiência histórica de 1000 vezes cair e 1000 vezes levantar.

Boal, AUGUSTO. Teatro do Oprimido e outras poéticas políticas. Ed12. Civilização Brasileira SA, Rio de Janeiro, 1991.

Freire, PAULO. Pedagogia do Oprimido. Ed 12.Paz e Terra.Rio de Janeiro, 1983.

SPIGOLON, Nima e NOGUEIRA, Adriano. Oprimido(s) da pedagogia ao teatro: Paulo Freire e Augusto Boal. São Paulo: Cártago Editorial, 2018. 